Jurnal ELKOM diterbitkan oleh Sekolah Tinggi Elektronika dan Komputer (STEKOM). Jurnal ELKOM sebagai sarana komunikasi dan penyebarluasan hasil penelitian, pemikiran serta pengabdian pada masyarakat

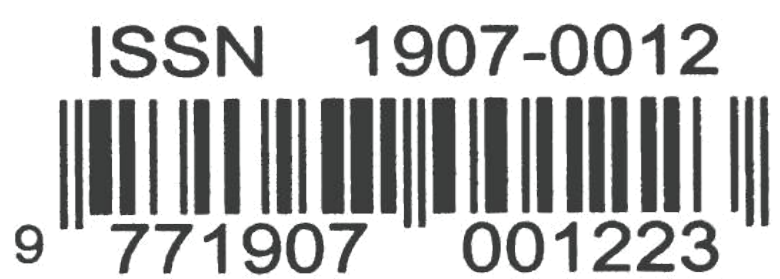

\begin{tabular}{lr}
\hline Perancangan Aplikasi Android Untuk Media Pembelajaran Budidaya Tanaman Secara \\
Hidroponik Dengan Metode Demon-Disco Leaming \\
Daniel Novianto & $1-8$ \\
\hline $\begin{array}{l}\text { Rancangan Bangun Alat Musik Piano, Harpa, Marching Bell Digital Berbasis Arduino } \\
\text { Menggunakan Cahaya Laser Dan LDR } \\
\text { Dendy Kumiawan }\end{array}$ & $9-19$ \\
\hline $\begin{array}{l}\text { Rancangan Bangun Sistem Peringatan Dini Bencana Banjir Pada Sungai Tuntang Ke- } \\
\text { dungjati Berbasis Arduino Menggunakan Teknologi IOT } \\
\text { lhsan Hidayat Ardi }\end{array}$ & $20-30$ \\
\hline $\begin{array}{l}\text { Alat Pendeteksi Gas Amoniak Pada Kamar Mandi Berbasis Arduino( Studi Kasus Diho- } \\
\text { tel Wisma Menorah Sampangan Semarang) }\end{array}$ & $31-37$ \\
\hline $\begin{array}{l}\text { Achmad Abdul Charis } \\
\text { Rancang Bangun Alat Penyotiran Barang Otomatis Berbasis Arduino Pada PT Wahana }\end{array}$ & $38-44$ \\
\hline $\begin{array}{l}\text { Prestasi Logistik Semarang } \\
\text { Yan Ilmas Puimera }\end{array}$
\end{tabular}

STEKOM

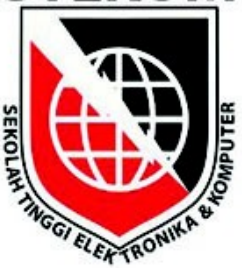

S T E K O M Sekolah Tinggi Elektronika dan Komputer SEMARANG 


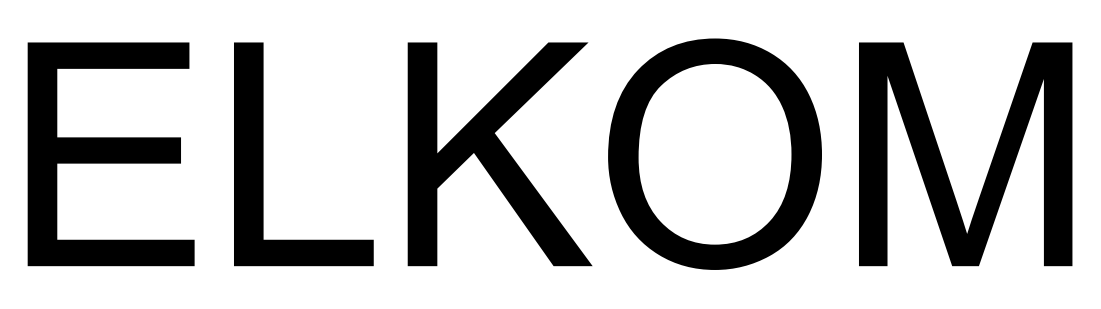

JURNAL ELEKTRONIKA DAN KOMPUTER

Penanggung Jawab :

Ketua Sekolah Tinggi Elektronika \& Komputer

Pemimpin Redaksi :

Sulartopo, S.Pd, M.Kom

Penyunting Pelaksana :

Dr. Ir. Drs. R. Hadi Prayitno, S.E, M.Pd

Dr. Ir. Agus Wibowo, M.Kom, M.Si, M.M

Sarwo Nugroho, S.Kom, M.Kom

Sekretaris Penyunting:

Ir. Paulus Hartanto, M.Kom

Mars Caroline Wibowo, S.T, MT. Tech

Sekretariat :

Dr. Unang Achlison, S.T, M.Kom

Djoko Soerjanto, S.E, M.Kom

Muhammad Sidik, S.Kom, M.Kom

Desain Grafis :

Setiyo Adi Nugroho,S.E, S.Kom

\footnotetext{
Alamat Redaksi :

Pusat Penelitian - Sekolah Tinggi Elektronika \& Komputer (STEKOM) Jl. Majapahit No. 605 Semarang Telp. 024-6710144 E-Mail :

elkom@stekom.ac.id
} 


\section{KATA PENGANTAR}

Puji syukur ke hadirat Tuhan Yang Maha Esa dengan terbitnya Jurnal elektronika dan computer (ELKOM) Edisi Desember 2018, Volume 11 Nomor 1 Tahun 2018 dengan artikel-artikel yang selalu mengikuti perkembangan IImu Pengetahuan dan Teknologi dalam bidang elektronika dan computer. Semua artikel yang dimuat pada Jurnal elektronika dan komputer (ELKOM) ini telah ditelaah oleh Dewan Redaksi yang mempunyai kompetensi di bidang elektronika dan komputer. Pada edisi ini kami menyajikan beberapa topik menarik tentang penerapan elektronika dan komputer yaitu: "Perancangan Aplikasi Android Untuk Media Pembelajaran Budidaya Tanaman Secara Hidroponik Dengan Metode Demon-Disco Learning ", serta "Rancang Bangun Alat Musik Piano, Harpa, Marching Bell Digital Berbasis Arduino Menggunakan Cahaya Laser Dan Ldr (Studi Kasus SMP NU 07 Brangsong) ", selanjutnya "Rancang Bangun Sistem Peringatan Dini Bencana Banjir Pada Sungai Tuntang Kedungjati Berbasis Arduino Menggunakan Teknologi IOT ", dan "Alat Pendeteksi Gas Amoniak Pada Kamar Mandi Berbasis Arduino (Studi kasus dihotel wisma menorah sampangan Semarang)". "Rancang Bangun Alat Penyortiran Barang Otomatis Berbasis Arduino Pada Pt Wahana Prestasi Logistik Semarang ", Terima kasih yang mendalam disampaikan kepada penulis makalah yang telah berkontribusi pada penerbitan Jurnal ELKOM edisi kali ini. Dengan rendah hati dan segala hormat, mengundang Dosen dan rekan sejawat peneliti dalam bidang elektronika dan komputer untuk mengirimkan naskah, review, gagasan dan opini untuk disajikan pada Jurnal elektronika dan komputer (ELKOM) ini. Sebagai akhir kata, saran dan kritik terhadap Jurnal elektronika dan komputer (ELKOM) yang membangun sangat diharapkan. Selamat membaca.

Semarang, Desember 2018 


\section{DAFTAR ISI}

Kata

Pengantar

Daftar

Isi. .ii

1. Perancangan Aplikasi Android Untuk Media Pembelajaran Budidaya Tanaman Secara Hidroponik Dengan Metode Demon-Disco Learning, Daniel Novianto 1-8

2. Rancang Bangun Alat Musik Piano, Harpa, Marching Bell Digital Berbasis Arduino Menggunakan Cahaya Laser Dan Ldr (Studi Kasus SMP NU 07 Brangsong), Dendy Kurniawan .9-19

3. Rancang Bangun Sistem Peringatan Dini Bencana Banjir Pada Sungai Tuntang Kedungjati Berbasis Arduino Menggunakan Teknologi IOT, Ihsan Hidayat Ardi.... 20-30

4. Alat Pendeteksi Gas Amoniak Pada Kamar Mandi Berbasis Arduino (Studi kasus dihotel wisma menorah sampangan Semarang), Achmad Abdul Charis 31-37

5. Rancang Bangun Alat Penyortiran Barang Otomatis Berbasis Arduino Pada Pt Wahana Prestasi Logistik Semarang, Yan IImas Puimera $38-44$ 


\title{
Perancangan Aplikasi Android Untuk Media Pembelajaran Budidaya Tanaman Secara Hidroponik Dengan Metode Demon-Disco Learning
}

\author{
Daniel Novianto \\ Sekolah Tinggi Elektronika dan Komputer (STEKOM) \\ JI. Majapahit 605 \& 304 Semarang, Indonesia \\ Email : humas@stekom.ac.id
}

\begin{abstract}
ABSTRAK
Pemanfaatan perangkat mobile dengan sistem operasi android yang digunakan sebagai media pendukung serta suplemen dalam meningkatkan hasil belajar dipadukan dengan metode demontrasi dan discovery learning atau demon-disco learning sangat diperlukan untuk membantu siswa dalam meningkatan hasil belajar pada mata pelajaran kompetensi kejuruan Budidaya tanaman secara hidroponik di SMK Kristen Terang Bangsa, karena penggunaan aplikasi berbasis android dapat memberikan pengalaman baru mengenai pemanfaatan teknologi informasi dan komunikasi, serta memberikan kesempatan kepada siswa untuk dapat belajar secara lebih mandiri.

Konsep yang dipilih sebagai media pembelajaran yaitu memaparkan materi tentang pengertian, pengenalan bagian-bagian, jenis -jenis, serta quiz berisi soal tentang budidaya tanaman secara hidroponik.Penelitian ini menggunakan metode pengembangan produk Research and Development $(\mathrm{RnD})$, dengan memakai 6 dari 10 tahap penelitian yaitu potensi dan masalah, pengumpulan data, desain produk, validasi desain, perbaikan desain, uji Coba produk.

Hasil dari penelitian ini adalah menghasilkan media pembelajaranberupa aplikasi berbasisandroid. Adapun nilai validitas dari ahli media sebesar 2,6 dimana dinyatakan layak, sedangkan nilai validitas dari ahli materi sebesar 3,6 dimana dinyatakan layak, dan mampu meningkatkan nilai rata-rata pada mata pelajaran kompetensi kejuruan budidaya tanaman secara hidroponik di SMK Kristen Terang Bangsa yang semula 67 (dengan 13 siswa yang belum mencapai KKM) menjadi 80 (dengan 4 siswa yang belum mencapai KKM).
\end{abstract}

Kata kunci: android, media, media pembelajaran, hidroponik.

\section{PENDAHULUAN}

Pengaruh

perkembanganteknologi informasi telah memasuki berbagai sendi kehidupan, termasuk dunia pendidikan khususnya pembelajaran telah diintervensi oleh keberadaan teknologi.Seiring dengan perkembangan aplikasi teknologi informasi dalam dunia pendidikan, maka berbagai bahan pembelajaranpun telah diproduksi dan dikonsumsi oleh pembelajar melalui media teknologi informasi dalam bentuk kemasan yang sangat bervariasi.Perkembanganhandpho ne pada saat ini telah memasuki era smartphone dengan berbagai kelebihannya. Smartphone hadir 
dengan berbagai fitur yang menarik yang akan membantu kita layaknya sebuah computerdekstop. Sistem android sudah banyak dikembangkan, salah satunya dalam dunia pendidikan. Sistem android dalam dunia pendidikan membuat siswa lebih mengeksplorasi kemampuannya dan membuat pembelajaran menjadi lebih efektif, karena dihubungkan dengan sistem database.Metode pembelajaran yang sesuai dengan penggunaan sistem android adalah demonstrasi dan discovery learningatau Demon-Disco Learning.

Setelah melakukan pengamatan awal di SMK Kristen Terang Bangsa Semarang, didapat informasi bahwa nilai rata- rata mata pelajaran produktif kompetensi keahlian Agribisnis Tanaman Pangan dan Holtikultura di SMK Kristen Terang Bangsa dari tahun ajaran 2012/2013, 2013/2014, 2014/2015 nilai ratarata yang paling rendah adalah nilai mata pelajaran Budidaya Tanaman Secara Hidroponik yaitu sebesar 75,6 dibandingkan dengan kelima mata pelajaran produktif kompetensi keahlian Agribisnis Tanaman Pangan dan Hortikultura di SMK Kristen Terang Bangsa. Salah satu cara untukmeningkatkan kualitas belajar siswa pada mata pelajaran kompetensi kejuruan Budidaya tanaman secara hidroponik adalah dengan memanfaatkan perangkat teknologi informasi dan komunikasi.
Penelitian ini bertujuan untuk memanfaatkan perangkat mobile dengan sistem operasi android agar dapat digunakan sebagai media pendukung serta suplemen dalam meningkatkan hasil belajar dipadukan dengan metode demontrasi dan discovery learning atau demondiscolearning. Peranan aplikasi berbasis android adalah sebagai aplikasi yang berjalan di sistem operasi android dengan tujuan membantu siswa dalam peningkatan hasil belajar pada mata pelajaran kompetensi kejuruan Budidaya tanaman secara hidroponik, maka judulyang akan diambil adalah "Perancangan Aplikasi Android untuk Media Pembelajaran Budidaya Tanaman Secara Hidroponik dengan Metode Demon-Disco Learning di SMK Kristen Terang Bangsa Semarang".

\section{LANDASAN TEORI}

\section{Media}

Media merupakan alat perantara yang diciptakan untuk menyalurkan pesan dengan tujuan agar pemakai dapat lebih mudah dalam mencapai suatu tujuan. Media dibagi jenisnya berdasarkan indera yang terlibat[ CITATION Bre08 VI 1033 ] yaitu:media audio atau suatu alat media yang isi pesannya hanya dapat diterima melalui indera pendengaran saja, media visual yang artinya semua alat peraga yang digunakan dalam proses belajar yang bisa 
dinikmati lewat panca-indera mata[ CITATION Dar93 V 1033 ], media audiovisual yang artinya media penyalur pesan dengan memanfaatkan indera pendengaran dan penglihatan [ CITATION Sud03 V 1033 ].

\section{Pembelajaran}

Pembelajaran adalah
proses interaksi rantara
pendidik dengan peserta didik
untuk mencapair tujuan
pembelajaran yang
baik.Tujuan pembelajaran
sebagai tujuan perilaku yang
hendak dicapai atau yang
dapat dikerjakan oleh peserta
didik sesuai
kompetensi[ CITATION Mag77
$V 1033$ ].

\section{Media Pembelajaran}

Susilana dan Riyana
(2008) berpendapat bahwa
media pembelajaran adalah
teknologi pembawa pesan
yang dapat dimanfaaatkan
untuk keperluan
pembelajaran, jadi media
adalah keperluan bagi
guru.Media pembelajaran juga
dapat membantu siswa
meningkatkan pemahaman,
menyajikan data dengan
menarik dan terpercaya,
memudahkan penafsiran data,
dan memadatkan informasi
[ ClTATION Placeholder2
1033 ]. Fungsi utama media
pembelajaran adalah sebagai
alat bantu mengajar yang ikut
mempengaruhi iklim, kondisi,
dan lingkungan belajar.

\section{Android}

Android merupakan perangkat bergerak pada sistem operasi untuk telepon seluler yang berbasis Linux [ CITATION Ari11 V 1033 ].And roid menyediakan platform yang bersifat open source bagi para pengembang untuk menciptakan sebuah aplikasi. Android mulai secara bertahap melakukan sejumlah pembaruan atau update pada tahun 2008 untuk meningkatkan kinerja dari sistem operasi tersebut dengan menambahkan fitur baru, memperbaiki bug pada versi android yang sebelumnya

\section{Hidroponik}

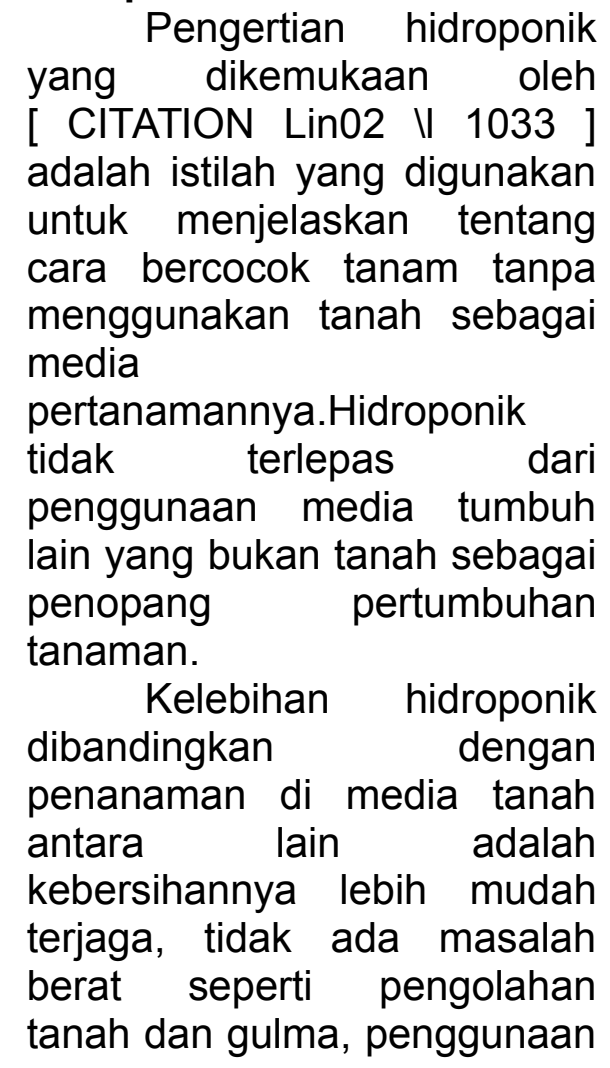


pupuk dan air sangat efisien, tanaman dapat diusahakan terus tanpa tergantung musim, tanaman berproduksi dengan kualitas yang tinggi, produktivitas tanaman lebih tinggi, tanaman lebih mudah diseleksi dan dikontrol dengan baik dan dapat diusahakan di lahan yang sempit[ CITATION Suh02 VI 1033 ].

\section{DemonstrasiLearning}

Metode demonstration adalah mengajar dengan cara memperagakan barang, kejadian, aturan dan urutan melakukan kegiatan, baik secara langsung maupun melalui penggunaan media pengajaran yang relevan dengan pokok bahasan atau materi yang sedang disajikan [ CITATION Muh05 VI 1033 ].Met ode demonstration adalah cara pembelajaran mendemonstrasikan

penggunaan alat atau atau melaksanakan kegiatan tertentu seperti kegiatan yang sesungguhnya [ CITATION Mar07 V 1033 ]. Dari uraian dan definisi di atas, dapat dipahami bahwa metode demonstration adalah di mana seorang guru memperagakan langsung suatu hal yang kemudian diikuti oleh siswa sehingga ilmu atau keterampilan yang didemonstrasikan lebih bermakna dalam ingatan masing-masing siswa.

\section{Discovery Learning}

\begin{abstract}
Belajar dengan penemuan adalah belajar untuk menemukan, dimana seorang siswa dihadapkan dengan suatu masalah atau situasi yang tampaknya ganjil sehingga siswa dapat mencari jalan pemecahan [ CITATION Mar06 VI 1033 ].Discovery adalah proses mental siswa hingga mampu mengasimilasikan suatu konsep atau prinsip. Proses mental tersebut antara lain: mengamati, mencerna, mengerti, menggolonggolongkan, membuat dugaan, menjelaskan, mengukur, membuat simpulan dan sebagainya, Sund dalam [ CITATION Roe12 VI 1033 ]. Pendapat lain dikemukakan oleh[ CITATION Han12 V 1033 ], discoverylearning merupakan suatu rangkaian kegiatan pembelajaran yang melibatkan secara maksimal seluruh kemampuan siswa untuk mencari dan menyelidiki secara sistematis, kritis, dan logis sehingga mereka dapat menemukan sendiri pengetahuan, sikap, dan keterampilan sebagai wujud adanya perubahan perilaku.
\end{abstract}

8. Demonstration and Discovery (Demon-Disco) Learning

Demontrasi dan

$\begin{array}{lr}\text { Discovery } & \text { (Demon-Disco) } \\ \text { Learning } & \text { adalah } \\ \text { penggabungan } & \text { metode } \\ \text { pembalajaran } & \text { yang } \\ \text { menggambarkan } & \text { peran } \\ & \text { guru }\end{array}$


untuk mempratikkan atau memperagakan sesuatu alat, kemudian para siswa bisa mencoba dan memaksimalkan kemampuannya untuk mencari dan menyelidiki secara sistematis sehingga siswa dapat menemukan sendiri pengetahuan, sikap dan ketrampilan.

\section{METODE PENELITIAN}

Metode penelitian dan
pengembangan (Research and
Development) adalah metode
penelitian yang digunakan untuk
menghasilkan produk tertentu, dan
menguji keefektifan produk
tersebut.Rancangan
pengembangan dengan desain $R$ \& $D$ dari Borg and Gall mempunyai 10 langkah yang bertujuan untuk mengembangkan dan memvalidasi produk, namun pada penelitian ini hanya akan diterapkan 6 langkah awal dalam pengembangan produk, sebagai berikut: (1) Potensi dan masalah: studi pustaka yaitu kaji teori dan hasil-hasil penelitian yang relevan, survei awal lokasi penelitian yaitu pada SMK Kristen Terang Bangsa untuk mengetahui profil dan datadata, mengumpulkan nilai rapot mata pelajaran budidaya tanaman secara hidroponik.

Pengumpulan data: merumuskan tujuan penelitian, menghasilkan gagasan yang kreatif dalam pengembangan, memperkirakan tenaga, waktu dan tempat. (3) Desain Produk: tahap ini dibahas tentang tahap-tahap membuat media pembelajaran matematika berbasis android. (4) Validasi

Desain: salah satu proses pengembangan yang dilakukan guna mengetahui tingkat keefektifan produk tersebut. Dalam penilaian menggunakan angket, terbagi atas 3 angket, yakni angket ditujukan bagi validator (para ahli desain), siswa (pengguna media), serta guru (para ahli materi).Target penilaian dari ahli validasi dinyatakan valid jika mencapai $65 \%$ dari nilai total dari seluruh pertanyaan. Perbaikan desain: dilakukan jikahasil produk menunjukkan bahwa desain yang dirancang oleh peneliti dianggap kurang valid, sehingga peneliti bertanggung jawab memperbaiki (revisi) rancangan desain hingga rancangan tersebut benar-benar dinyatakan valid dan layak untuk diterapkan. (6) Uji coba produk dilakukan SMK Kristen Terang Bangsa Semarang, desain uji coba dilakukan dengan pengelompokan data nilai yang diperoleh dari pembagian angket kepada para ahli desain dan ahli materi, subyek uji coba Validator ini terbagi atas kelompok ahli, yakni guru kompetensi kejuruan Agribisnis Tanaman Pangan dan Hortikultura, ahli multimedia, serta 20 siswa berlaku sebagai kelompok kecil, jenis data Data yang diperoleh pada penelitian ini yakni data kuantitatif dan data kualitatif, instrumen pengumpulan dengan data yang diperoleh dari informasi tentang daftar nilai ratarata ujian akhir semester kelas $X$ ATPH dari bagian kurikulum, dan 20 angket yang disebar kepada 
siswa kelas X-ATPH, teknik analisis data tahap pengolahan data dimulai dari penelitian pendahuluan hingga tersusunnya usulan penelitian. Data awal yang diperoleh adalah informasi tentang daftar nilai rata-rata ujian akhir semester kelas X-ATPH dari bagian kurikulum.

\section{HASIL DAN PEMBAHASAN}

Media pembelajaran ini dikembangkan dengan bantuan software Notepad++, Adobe Photoshop, Adobe Audition, 3D Blender, Coreldraw, dan MySQL. Pada hasil pengembangan ini, terdapat langkah-langkah dalam pembuatan desain gambar menggunakan

softwareAdobePhotoshop CS6, membuat Gambar Ikon Materi, Latian Soal, dan Keluar Menggunakan 3D Blennder, 4.2.3, membuat Gambar .PNG menjadi Gif menggunakan program gifmaker.me, merekam narasi melalui voice recorder pada telepon genggam dan mengedit narasi menggunakan Adobe Audition 1.5, membuat karakter animasi menggunakan Macromedia Flash, 4.2.6, membuat Sebuah Folder, sebuah folder dibuat dengan nama "danhid" ke dalam drive D. Folder ini digunakan untuk menempatkan semua file, ikon, logo, dan suara, pemprograman mengunakan Notepad++, pembuatan soal pembelajaran hidroponik dengan menggunakan fasilitas yang ada di dalam PhpAdmin yaitu SQL, Software utama yang digunakan untuk membangun sebuah APK adalah Command Prompt dengan perintah Cordova.

Penentuan kelayakan

penerapan aplikasi Android untuk media pembelajaran budidaya tanaman secara hidroponik dengan metode demon-disco learningdi SMK Kristen Terang Bangsa Semarangdiukur berdasarkan penilaian (validasi) dari para ahli yaitu ahli media, ahli materi dan validasi dari user pada uji coba produk. Hasil validasi dari ahli media dengan pengujian melalui angket yang berjumlah 10 pertanyaan, nilai yang diperolehadalah 2,6, kriteria ini berada diantara 2,1 - 3,0 yaitu tergolong dalam kategori valid, sehingga alat bantu presentasi ini dapat dikatakan layak. Hasil validasi dari ahli materi dengan pengujian melalui angket yang berjumlah 10 pertanyaanadalah 3,6 , kriteria ini berada diantara $3,26-4,00$ yaitu tergolong dalam kategori sangat valid, sehingga alat bantu presentasi ini dapat dikatakan layak. Berdasarkan data dari 20 responden dari siswa di SMK Kristen Terang Bangsa Semarang dengan 10 jumlah pertanyaan, diketahui bahwa hasil validasi penilaian dari pengguna adalah 3,17 . Kriteria ini berada diantara 3,1- 4,00yakni tergolong dalam kategori sangat valid. Berdasarkan data dari 20 responden dari siswa di SMK Kristen Terang Bangsa Semarang dengan 10 jumlah soal pertanyaan, diperoleh data sebelum user menggunakan produk terdapat $65 \%$ siswa yang belum mencapai nilai KKM, dan 
setelah user menggunakan produk mengalami penurunan yaitu hanya sebanyak $20 \%$ yang belum mencapai KKM dengan nilai ratarata evaluasi yang menggunakan aplikasi android untuk media pembelajaran dan tidak menggunakannya, telah diperoleh yaitu 67 untuk cara konvensional dan nilai 80 yang memakai media pembelajaran aplikasi android untuk media pembelajaran.

\section{SIMPULAN DAN SARAN}

Berdasarkan hasil penelitian perancangan aplikasi android untuk media pembelajaran budidaya tanaman secara hidroponik dengan metode demon-disco learning dapat disimpulkan sebagai berikut:

1. Penggunaan aplikasi android untuk media pembelajaran budidaya tanaman secara hidroponik dengan metode demon-disco learning dalam pembelajaran dapat meningkatkan minat belajar dan telah terbukti efektif.

2. Pembuatan aplikasi android dapat dilakukan melalui Notepad++, javascript, dan desain dibuat dengan menggunakan Photoshop, CorelDraw, Blender.

3. Kelemahan aplikasi android yaitu animasi berjalan tidak dapat bersamaan dengan suara.

4. Soal evaluasi sudah menggunakan model soal acak.

5. Akses aplikasi android di dalam perangkat mobile cukup ringan dikarenakan file yang dihasilkan saat 1 . proses build apk kecil.

6. Penambahkan soal evaluasi dapat dilakukan melalui pengeditan di control panel web.

7. Berdasarkan hasil pengujian validasi ahli media diperoleh nilai 2,6 termasuk kategori valid, hasil pengujian validasi ahli materi diperoleh nilai 3,6 termasuk kategori sangat valid, dan hasil pengujian validasi user diperoleh nilai 3,17 termasuk kategori sangat valid, sehingga dapat dikatakan bahwa media pembelajaran tersebut memenuhi kriteria nilai 3-4 termasuk dalam kategori layak, sehingga media ini dapat digunakan di SMK Kristen Terang Bangsa Semarang.

8. Berdasarkan analisa pembahasan diperoleh data sebelum user menggunakan produk terdapat $65 \%$ siswa yang belum mencapai nilai KKM, dan setelah user menggunakan produk mengalami penurunan yaitu hanya sebanyak $20 \%$ yang belum mencapai KKM sehingga penelitian perancangan aplikasi android untuk media pembelajaran budidaya tanaman secara hidroponik dengan metode demon-disco learning dapat dikatakan efektif

9. Produk atau media pembelajaran yang dibuat untuk menunjang penelitian berupa aplikasi android yang disambungkan dengan database sehingga setiap siswa memiliki akun login untuk mengakses modul dan latihan soal sehingga guru juga dapat melihat hasil latihan soal pada database sebagai tolak ukur keberhasilan pembelajaran

\section{SARAN}

Berdasarkan

hasil

penelitian, pembahasan dan kesimpulan di atas, maka saran yang dapat diberikan pada penelitian ini adalah:

Pengembangan media pembelajaran menggunakan aplikasi androidyang lebih lanjut, diusahakan dapat memperbanyak animasi 3D.

2. Pengembangan media pembelajaran menggunakan aplikasi android untuk selanjutnya perlu dikembangkan media 
pembelajaran pada mata pelajaran yang lain.

\section{DAFTAR PUSTAKA}

Arifianto, T. (2011).Membuat Interface Aplikasi Lebih Keren dengan LWUIT. Yogyakarta: Andi Publisher

Arsyad, A. (2011). Media Pembelajaran. Jakarta: Rajawali Pers.

Brets, R. (2008). Media Pembelajaran dan Aplikasinya. Jakarta: Gramedia Pustaka Utama.

Daryanto.(1993). Media Visual Untuk Pengajaran Teknik. Bandung: Tarsito.

Hanafiah, N., \& Cucu, S. (2012). Konsep Strategi Pembelajaran. Bandung: PT. Rafika Aditama.

Lingga, P. (2002). Hidroponik: Bercocok Tanam Tanpa Tanah. Edisi Revisi. Jakarta: Penebar Swadaya.

Magner, G. R. (1977). The Condition of Learning. New York: Holt Rinehart and Winston.

Markaban.(2006). Model Pembelajaran Matematika dengan Pendekatan Penemuan Yogyakarta: Terbimbing. Pendidikan Nasional Pusat Pengembangan dan Penataran Guru Matematika.

Martinis, Y. (2007). Kiat Membelajarkan Siswa. Jakarta: Gaung Persada Press.

Muhibbin, S. (2005). Psikologi Belajar. Jakarta: Raya Grafindo Perkasa.

Roestiah.(2012). Strategi Belajar Mengajar. Jakarta: Rineka Cipta.

Sudjana, N., \& Rivai, A. (2003).Media Pengajaran. Bandung: CV. Sinar Baru.
Suhardiyanto, H. (2002). Teknologi Hidroponik. Modul Pelatihan Aplikasi Teknologi Hidroponik untuk Pengembangan Agribisnis Perkotaan. Bogor: CREATA-IPB dan Depdiknas 